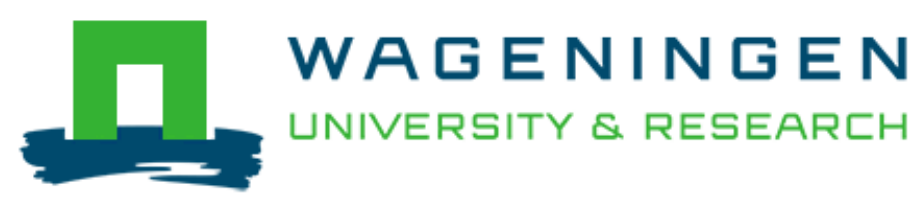

Greening flood protection through knowledge processes: lessons from the Markermeer dikes project in the Netherlands

Janssen, S., van Tatenhove, J. P. M., Mol, A. P. J., \& Otter, H. S.

This article is made publically available in the institutional repository of Wageningen University and Research, under article 25fa of the Dutch Copyright Act, also known as the Amendment Taverne.

Article $25 \mathrm{fa}$ states that the author of a short scientific work funded either wholly or partially by Dutch public funds is entitled to make that work publicly available for no consideration following a reasonable period of time after the work was first published, provided that clear reference is made to the source of the first publication of the work.

For questions regarding the public availability of this article, please contact openscience.library@wur.nl.

Please cite this publication as follows:

Janssen, S., van Tatenhove, J. P. M., Mol, A. P. J., \& Otter, H. S. (2017). Greening flood protection through knowledge processes: lessons from the Markermeer dikes project in the Netherlands. Regional Environmental Change, 17(2), 551-563. DOI: $10.1007 / \mathrm{s} 10113-016-1040-1$

You can download the published version at:

https://doi.org/10.1007/s10113-016-1040-1 


\title{
Greening flood protection through knowledge processes: lessons from the Markermeer dikes project in the Netherlands
}

\author{
Stephanie K. H. Janssen ${ }^{1,2}$ Jan P. M. van Tatenhove ${ }^{3}$ Arthur P. J. Mol ${ }^{3}$. \\ Henriëtte S. Otter ${ }^{4}$
}

Received: 4 April 2014/Accepted: 8 August 2016/Published online: 3 September 2016

(c) Springer-Verlag Berlin Heidelberg 2016

\begin{abstract}
Greening flood protection (GFP) is increasingly recognized as an adaptive and flexible approach to water management that is well suited to addressing uncertain futures associated with climate change. In the last decade, GFP knowledge and policies have developed rapidly, but implementation has been less successful and has run into numerous barriers. In this paper, we address the challenge of realizing green flood protection goals by specifically considering knowledge in the decision-making of a Dutch flood protection project in Lake Markermeer. In this project, an ecological knowledge arrangement and a traditional flood protection knowledge arrangement are
\end{abstract}

Editor: Sarah Gergel.

Electronic supplementary material The online version of this article (doi:10.1007/s10113-016-1040-1) contains supplementary material, which is available to authorized users.

Stephanie K. H. Janssen

Stephanie.janssen@deltares.nl

Jan P. M. van Tatenhove

jan.vantatenhove@wur.nl

Arthur P. J. Mol

Arthur.Mol@wur.nl

Henriëtte S. Otter

henriette.otter@deltares.nl

1 Scenarios and Policy Analysis, Deltares, P.O. Box 177, 2600 MH Delft, The Netherlands

2 Faculty of Technology, Policy and Management, Delft University of Technology, P.O. Box 5015, 2600 GA Delft, The Netherlands

3 Environmental Policy Group, Wageningen University, P.O. Box 8130, 6700 EW Wageningen, The Netherlands

4 Subsurface and Groundwater Systems, Deltares, P.O. Box 85467, 3508 AL Utrecht, The Netherlands compared and their interactions analysed. The analysis provides insight into the specific difficulties of implementing GFP measures and identifies ways to realize GFP goals. The primary challenge is twofold: First, a self-reinforcing cycle of knowledge production and decisionmaking in the flood protection domain inhibits the introduction of innovative and multifunctional approaches such as GFP; second, the distribution of power is severely unbalanced in terms of ecological enhancement and flood protection, favouring the latter. Implementation of GFP requires structural change and the integration of ecological and flood protection knowledge and policy. Potentially rewarding routes towards this integration are the exploration of shared interests in GFP and the creation of mutual dependency between knowledge arrangements. The case study and the insights it provides show that GFP is far from mainstream practice and that implementation requires serious effort and courage to break with historical practices.

Keywords Knowledge arrangements - Flood protection * Greening flood protection - Climate change - Decisionmaking

\section{Introduction}

Climate change effects such as sea level rise and more extreme storm events directly impact the need for flood protection. For example, in the Netherlands, the probability of flooding increases by a factor 10 for each $50-80 \mathrm{~cm}$ of sea level rise (Aerts and Botzen 2013; Aerts et al. 2008). In addition to an increased probability of flooding, the uncertainty associated with climate change is of central concern in planning. Flood protection measures are likely 
to be implemented for timespans of 50-100 years, and over that time, climate change may have more or less impact. This has caused many authors to call for no-regret measures (Cheong et al. 2013), adaptive strategies and flexible designs that can adjust to changing circumstances (Gersonius et al. 2013; Aerts and Botzen 2013). In particular, greening flood protection (GFP)—e.g. through ecological engineering, ecosystem-based adaptation and working with nature-is advocated for dealing with climate change in coastal areas (PIANC 2011; Hale et al. 2009; Spalding et al. 2013; Martin and Watson 2016). GFP includes nature and environmental interests in the development of coastal infrastructure, and as such, it enhances ecosystems while achieving flood protection objectives (Janssen et al. 2014a). Protection against flooding is provided by natural elements such as mangroves, salt marshes, or oyster reefs to attenuate waves, stabilize shorelines, provide a direct barrier (Gedan et al. 2011; Van Wesenbeeck et al. 2014) or support the natural distribution of sand and sediments. While strongly dependent on local conditions, GFP approaches can enhance biodiversity, improve water quality (Coen et al. 2007; Spencer and Harvey 2012) and make ecosystems more resistant and resilient (Hale et al. 2009). GFP measures are valued as more sustainable, costeffective and ecologically sound than conventional flood protection (Temmerman et al. 2013) and are thought to improve the overall resilience of coastlines by providing a range of ecosystem services (Hale et al. 2009). Often, GFP solution function in combination with existing hard infrastructure and sustainable application of ecosystem engineers requires assessment of both the services and disservices they provide (Ayanu et al. 2015).

While scientists stress the urgency of timely adaptations to climate change, implementation requires continuing attention and improved understanding of ecological processes (Runhaar et al. 2012; Kabat et al. 2005). The implementation of GFP efforts has advanced slowly, and up until now, large-scale applications remain scarce (Temmerman et al. 2013). Decision-making about and the realization of these multifunctional approaches remain a challenge (Van Broekhoven and Vernay 2011; Mulder et al. 2011). GFP governance arrangements and knowledge are different from conventional flood protection governance efforts and knowledge (Korbee and Van Tatenhove 2013; Janssen et al. 2014a). This paper focuses on knowledge in decision-making related to green flood protection strategies.

Knowledge in decision-making associated with green flood protection efforts is challenging for at least three reasons. First, greening is an innovative practice in flood protection, requiring the development of new knowledge on not yet proven technologies and strategies. Second, GFP knowledge is different from conventional flood protection knowledge. While uncertainties are minimized in the latter approach by the design of systems that can be controlled and predicted, GFP knowledge builds upon the natural variability of ecosystems and is therefore inherently unpredictable and uncertain (Van den Hoek et al. 2013). Third, GFP requires the integration of multiple knowledge disciplines such as ecology, engineering and geomorphology (Mitsch and Jørgensen 2003). These characteristics imply a different approach towards knowledge development and use that has commonly been applied (Giebels et al. 2013; Brugnach and Ingram 2012). The aim of this paper is therefore to improve our understanding of knowledge in decision-making and the enabling factors related to the implementation of GFP. Our research is based on the analysis of a case study in the Netherlands: the Markermeer dike reinforcement project.

This paper begins by introducing the concept of knowledge arrangements. This concept is introduced to provide an analytical understanding of knowledge in GFP decision-making. Next, the materials and methods used in this study are discussed, followed by an introduction of an in-depth case study of the Markermeer dike reinforcement project. Then the results of the case study are presented, followed by a discussion on factors that enable the implementation of green flood protection measures. Final section presents the conclusions.

\section{Policy-knowledge interactions: knowledge arrangements}

In addressing knowledge in decision-making, we distinguish three research lines. One line of research covers the interactions between science (or knowledge) and policy in a 'science-policy interface' (Turnhout et al. 2007). In stimulating the development of useful knowledge, this body of research is devoted to closing the gap between science and policy (Van de Riet 2003; McNie 2007) and to understanding knowledge production processes (Seijger et al. 2014; Hegger et al. 2012). A second line of research aims to understand and combine different types (e.g. multiple disciplines) or sources of knowledge (e.g. lay and expert knowledge) (Eshuis and Stuiver 2005; Hunt and Shackley 1999; Petts and Brooks 2006; Rinaudo and Garin 2005). A third line of research recognizes that within a policy domain or on a specific policy issue, knowledge and policy have similar orientations and backgrounds and are co-produced (Edelenbos et al. 2011; van der Molen et al. 2016), and they highlight the conflicts between such knowledge-policy fields (Van Buuren and Edelenbos 2004; Muñoz-Erickson 2013). While this research line has grown over the last decade, conflicts between different knowledge-policy fields often remain poorly understood and 
unaddressed (Muñoz-Erickson 2013). This paper contributes to an improved understanding of interactions between knowledge-policy fields and the factors determining this interaction.

\section{Interacting knowledge arrangements}

We apply the conceptual framework of interacting knowledge arrangements, as introduced in a paper by Janssen et al. (2014a). This framework allows for a structured analysis of interactions among knowledge-policy fields, highlights the interrelatedness of knowledge and context, and focuses on stability and change within knowledge arrangements. Knowledge arrangements are inspired by the idea of ways of knowing (Feldman et al. 2006; Lejano and Ingram 2009; Van Buuren 2009) and are based on the policy arrangement approach (Van Tatenhove et al. 2000). A knowledge arrangement is defined as 'the dynamic interdependent constellation of a knowledge base and the policy arrangement within a specific domain' and has two main elements: the policy arrangement and the knowledge base (Janssen et al. 2014a).

A policy arrangement is a temporary stabilization of the content and organization of a policy domain (Van Tatenhove et al. 2000, p. 54). It is identified and analysed using four interrelated dimensions:

1. Actors and coalitions involved in policies

2. Discourses that capture views and narratives of these actors

3. Resources applied by actors (e.g. money, knowledge, responsibility, facilities)

4. Formal and informal rules of the policy game

Although in the policy arrangement, knowledge is recognized as a resource contributing to power in a policy domain, the process of creating a knowledge base is not given central stage in this theory. Following Hommes (Hommes 2008; Hommes et al. 2009), a knowledge base is defined as a collection of knowledge sources (e.g. research reports, models, data, practical experiences, etc.) that have been made explicit and are related to a specific policy arrangement.

As a multifunctional approach, greening flood protection combines different knowledge bases and policy arrangements, or different knowledge arrangements. Therefore, interactions between multiple knowledge arrangements are key to the GFP process (Fig. 1). Interactions among knowledge arrangements can be classified into four modes of interaction (Janssen et al. 2014a): separation, cooperation, integration or unification. Separation relates to a situation in which knowledge arrangements operate in isolation from one another. Here, no interaction among actors is involved, rules and discourses are unrelated,

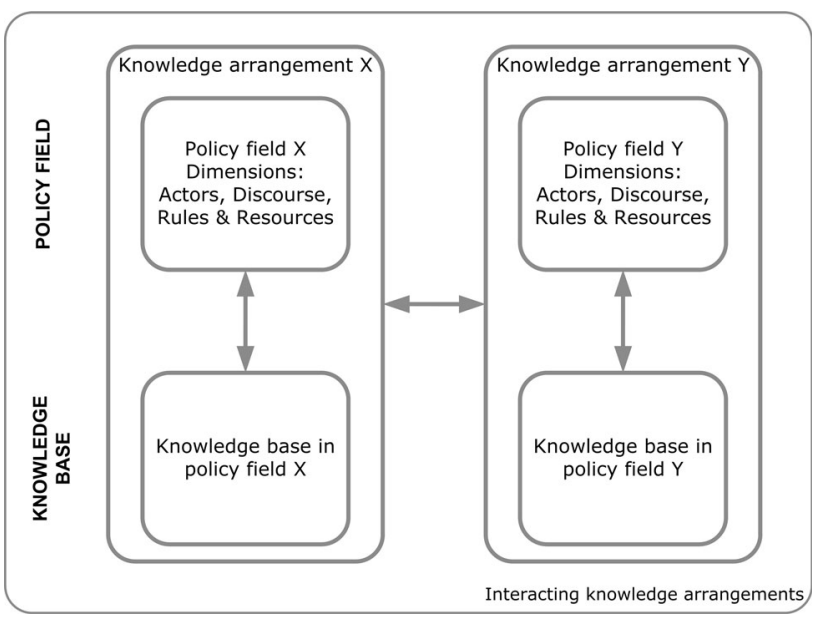

Fig. 1 Interacting knowledge arrangements (Janssen et al. 2014a)

resources remain separate and the knowledge bases are different and unrelated. Cooperation involves communication among actors and coordination of some activities. The knowledge base is shared and attuned. Integration implies a merger of the initial knowledge arrangements forming a new, temporary and local knowledge arrangement (e.g. in a project). The initial knowledge arrangements coexist, but not at that specific place and time. Actor coalitions combine into a single coalition, collective rules and discourses form, and one knowledge base integrates the two fields. Unification relates to the situation where a new knowledge arrangement becomes permanent and replaces the initial knowledge arrangements.

\section{Materials and methods}

In order to understand knowledge in GFP decision-making, a qualitative case study analysis was performed. The Markermeer dike reinforcement project in the Netherlands was selected as the single case for in-depth analysis. For this project, the Dutch government formulated a plan to facilitate 'synergy between flood protection and ecology' in the area (Ministerie van V\&W 2009); one of the design options in the project-the 'shore dike'-provided an excellent opportunity to test this plan.

Data collection was performed between October 2012 and July 2013. Our analysis ranges from 2009, when the shore dike solution was introduced, to February 2013, when the preferred designs were selected. Data were collected between October 2012 and July 2013 through formal interviews $(9 \times)$, informal interviews with project participants (i.e. without an approved interview report, $9 \times$ ), attending public and project meetings $(4 \times)$, and analysis of project documentation. We had full access to project documentation, including internal writings, meeting minutes, 
e-mail correspondence and (formal) reports. The formal interviews were semi-structured in nature and were based on the 'clean language' approach, which aims to minimize the unintentional influence of the interviewer on the interviewee to rule out bias (Sullivan and Rees 2008; Van Helsdingen and Lawley 2012). In January 2014, preliminary results of the analysis were discussed with a representative of the project.

The research followed three successive steps. First, the knowledge arrangements in the case study were identified. Second, interactions among these arrangements were analysed. Third, factors enabling integration were determined. Steps one and two were based on empirical data and were informed by our conceptual framework. Step three combines empirical findings with the wider literature.

\section{Case study: the Markermeer dike reinforcement project}

The Markermeer dikes are located in the north of the Netherlands and provide protection against flooding from Lake Markermeer. Lake Markermeer is a fresh waterbody that was created after damming and partial reclamation of the former Zuiderzee Sea. The construction of the Afsluitdijk dam in 1932, the Houtribdijk dam in 1976 and significant land reclamation projects (Flevopolder and Noordoostpolder) resulted in better protection against flooding, increased fresh water availability and created new agricultural land in the region (Lammens et al. 2008). Initially, Lake Markermeer was also planned for reclamation. However, this plan was formally rejected in 2002. Subsequently, attention has shifted to the condition of the dikes and the ecological quality of the lake.

In 2006, the condition of the dikes along Lake Markermeer was assessed. The assessment concluded that 33 kilometres of dike between Amsterdam and Hoorn did not meet the legally required flood protection norm, or the ability to withstand a $1 / 10,000$ years probability storm. The local water board, Hoogheemraadschap Hollands Noorderkwartier (HHNK) became responsible for the execution of the dike reinforcements, which were to be completed by 2016 .

In addition to flood protection, the ecological status of Lake Markermeer was an important concern. The lake had been subject to severe ecological decline since the construction of the Houtribdijk Dam. The water was turbid, lacked nutrients and was home to a decreasing numbers of birds, fishes and plants. In 2008, a collaboration of governmental authorities developed an agenda for the future, involving plans for an 'ecological robust lake' (ERL). This ERL includes clear water zones along the coast, gradients between clear and turbid water, transitional zones between land and water and an improved ecological relationship between aquatic and terrestrial systems (Stuurgroep_TMIJ 2008).

\section{The shore dike: innovative design with GFP potential}

HHNK developed and assessed different design options for dike reinforcement. Initially, these designs were more traditional, with common reinforcement options such as enlarging the existing dike on the inner or outer side or using construction techniques such as sheet pilling. However, these options were too expensive, too large and too complex to be realized alone or in combination. In 2009, alternative options for dike reinforcement were explored. One of the outcomes was the 'shore dike'. The shore dike is a body of sand located on the lake side of the existing dike (Fig. 2). The flood projection function of the original dike is taken over by the shore dike. The shore dike is an innovative design that contrasts with traditional design options in that it is a 'soft' solution to flood management within a lake. The focus of this case study analysis is on the knowledge development and decision-making related to the shore dike. The shore dike was actively considered as a green flood management strategy.

From a flood protection perspective, the shore dike was attractive as a potentially cheaper alternative to traditional methods and because construction would be far less complex. The use and value of the current dike makes radical changes or enlargement of the dike difficult to realize. Houses are built against the dike, a bicycle track runs on top of it and a regional road connecting surrounding communities is on the landside verge of the dike. Moreover, the dike is an official monument, which means that the cultural and landscape values of the dike are to be respected. The shore dike does not affect the existing dike, and its construction would not need to interfere with the current use of the existing dike, as construction activities could be conducted from the lake side.

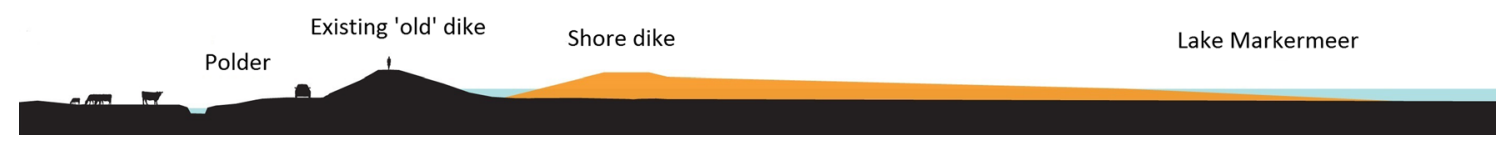

Fig. 2 Cross-section of a 'Basic Flood Protection' shore dike (Van der Linde et al. 2012) 
The soft character of the shore dike also makes it interesting from an ecological perspective. Soft means that the structure is not covered with stone but with sand, clay or vegetation. The shore dike may provide added ecological value through a gradual slope that allows for greater transitional zones between land and water. In this way, the shore dike would contribute to the realization of an ERL.

\section{Case study results}

After introduction of the shore dike concept in 2009, development and design proceeded in two different directions: a flood protection direction and an ecological direction. In February 2013, HHNK selected the basic flood protection (BFP) shore dike as the preferred design for implementation along one-third of the total dike span. However, this BFP design did not compromise any ecological elements (Fig. 2). In this section, we analyse the knowledge arrangements that emerged in the flood protection domain and in the ecological domain. Then, we assess the interactions among these knowledge arrangements. Figure 3 illustrates the timeline of the knowledge development and decision-making processes.

\section{Two knowledge arrangements}

Two different knowledge arrangements can be discerned in the case study: a flood protection knowledge arrangement and an ecological knowledge arrangement.

\section{Knowledge arrangement: 'flood protection shore dike'}

Flood protection in the Netherlands is rooted in a tradition of fighting against water (Wiering and Arts 2006), which is characterized by hard constructions such as dikes, dams, levees and storm surge barriers (Van den Hoek et al. 2012). Technical approaches and engineers dominate in this domain (Van Koningsveld et al. 2003). Up until today, flood protection has been a powerful policy arena in the Netherlands (Van Buuren et al. 2010). While changes in this hegemonic management strategy are noticed and more integrated approaches are being pursued (Van Der Brugge et al. 2005; Woltjer and $\mathrm{Al}$ 2007), today's flood protection efforts remain largely independent of other domains such as spatial planning or nature conservation; they remain strongly embedded in powerful sectoral organizations (Van Buuren et al. 2010; Wiering and Arts 2006).

In the Markermeer dike reinforcement project, HHNK is by law the authority responsible for guaranteeing protection against flooding. For the dike reinforcement project,

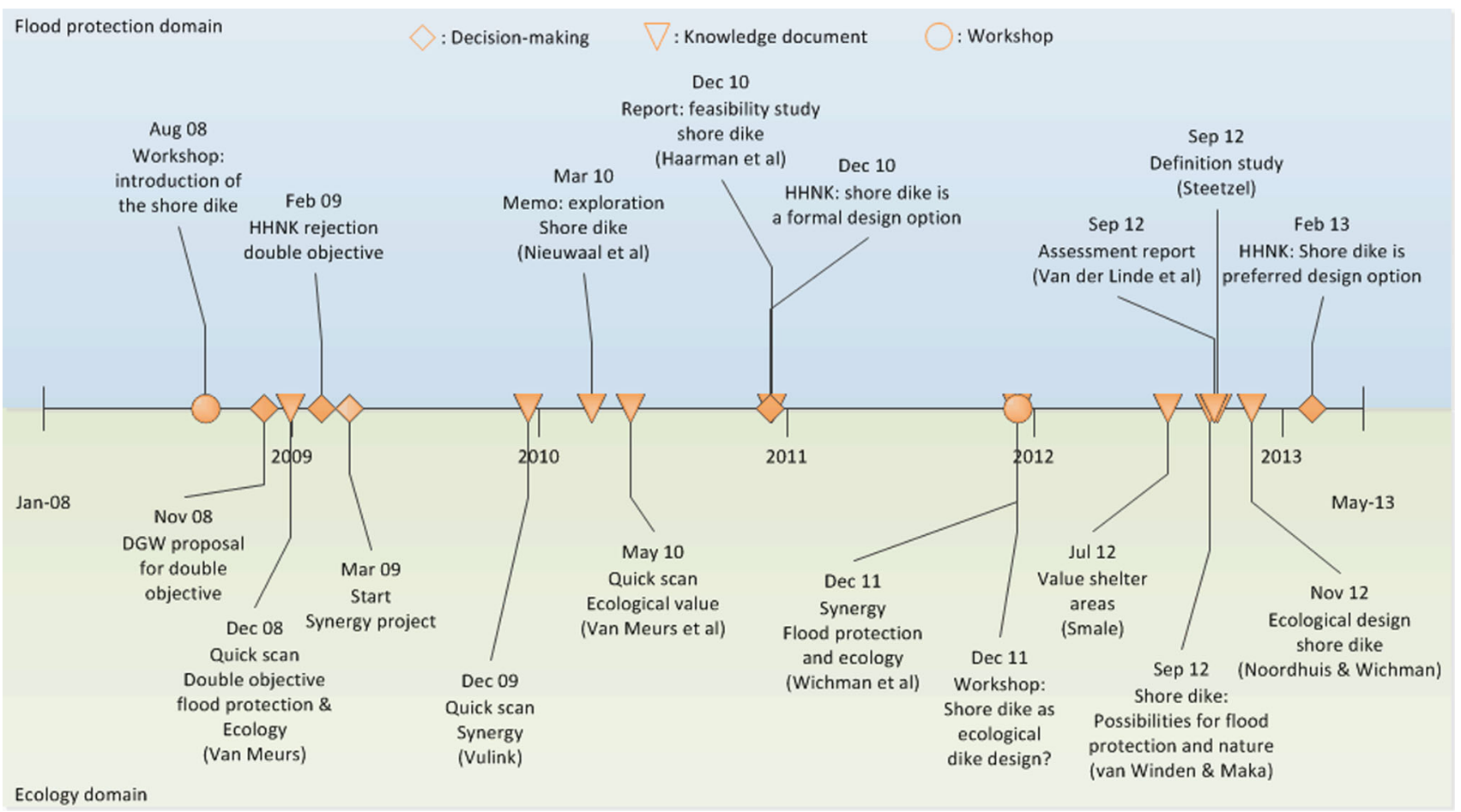

Fig. 3 Timeline of the shore dike design and decision-making process. The shore dike was designed and developed in two different domains: the flood protection domain (upper half in blue) and the ecological domain (lower half in green). The timeline represents the main decisions (diamond milestones), knowledge documents (triangle milestones) and workshops (circle milestones) (color figure online) 
HHNK requests subsidies from the second high water protection program (HWBP-2). HWBP-2 falls under the Ministry of Infrastructure and Environment's purview. In total, 88 flood protection projects fall under this subsidy programme. The criteria for receiving a grant are costefficiency, robustness (project life of at least 50 years) and appropriateness (for flood protection only) of the flood protection solution. HWBP-2 imposes a strict schedule upon projects.

After the introduction of the shore dike idea, HHNK and HWBP initiated an exploratory study into the concept and possible costs and benefits of the shore dike (Nieuwaal et al. 2010). The outcome led to a follow-up study into the feasibility of the shore dike, with an assessment of three different shore dike alternatives (Haarman et al. 2010). Based on this study, HHNK decided to include the shore dike in the EIA process and to start a definition study, which further defined the shore dike design in order to compare it with other design options (Steetzel 2012). Based on an assessment report comparing design alternatives for each dike section (Van der Linde et al. 2012), HHNK formally decided on its preferred designs in February 2013. For almost one-third of the dike reinforcement length, the shore dike was the preferred design.

\section{Knowledge arrangement: 'ecological shore dike'}

Combining flood protection and ecology is a rather innovative approach in flood protection management. Concepts such as ecosystem-based management (Barbier et al. 2008; Temmerman et al. 2013; Katsanevakis et al. 2011), ecological engineering (Borsje et al. 2011; Mitsch and Jørgensen 2003) and building with nature (Van Slobbe et al. 2013) represent similar ideas, where ecosystem dynamics and nature conservation are included in infrastructure design. Over the last decade, these approaches have been subject to extensive knowledge development and increasing political and policy support.

In 2008, the national government expressed interest in looking for possibilities that fully integrate ecology and flood protection in the reinforcement of the Markermeer dikes (Ministerie van V\&W 2009). These dikes were particularly interesting for the application of this approach, given the poor ecological status of the lake and the plans to promote an ERL. The water policy directorate (DGW) explored possibilities for synergy along the dike's length (Van Meurs 2008) and proposed to give the dike reinforcement project a double objective. This proposal was rejected by HHNK, claiming that such a change in the dike reinforcement project would not fit the project conditions and lead to delays.
As such a separate project was initiated and executed by Rijkswaterstaat (RWS), the executive directorate of the Ministry of Infrastructure and Environment. The aim of the 'synergy' project was to find alternative designs for dike reinforcement projects in which flood protection and ecology could be combined (personal communication with a representative of the Ministry, 13 June 2013).

The shore dike became the prime focus of the synergy project. The added ecological value of the shore dike was explored (Van Meurs et al. 2010). Two studies looked for possible cost reduction by connecting the shore dike with the ERL project 'shelter areas' (involving structures to enhance biodiversity and clear water) (Smale et al. 2012; Wichman et al. 2011). But these were not found. A workshop was organized together with HHNK (December 2011) in which possible ecological designs and related implications were explored. Noordhuis and Wichman (2012) further elaborated on the outcomes. In 2012, a coalition of nature organizations tried to push the development of an ecological shore dike by providing attractive images (Van Winden and Maka 2012).

The synergy project aimed to combine flood protection and ecology, but the studies primarily covered ecological aspects of the shore dike. In none of the studies, the relationship between ecological efforts and flood protection was evaluated. Nature protection organizations were invited and contributed to workshops and took the initiative to develop images of the shore dike.

\section{Comparing knowledge arrangements}

In our analysis, we found two clearly demarcated and contrasting knowledge arrangements (Table 1): a dominant and powerful flood protection knowledge arrangement and a less powerful ecological knowledge arrangement. The flood protection knowledge arrangement had ample financial resources (HWBP subsidy) and decision-making power (responsibility for the dike reinforcement), and flood protection objectives were defined in the Water Act. The knowledge base was effective: The successive flood protection reports resulted in a preferred design for dike reinforcement. In contrast, the ecological knowledge arrangement received funding for research but had no decision-making capabilities. The emphasis on synergy was not supported by strict obligations, and a formal relationship with ERL plans was not established. The ecological knowledge base remained exploratory and was also more scattered among the separate initiatives pursued by the synergy project and the coalition of nature organizations. 
Table 1 Comparing knowledge arrangements for flood protection and ecological values

\begin{tabular}{|c|c|c|}
\hline & Flood protection knowledge arrangement & Ecology knowledge arrangement \\
\hline Actors & HWBP, HHNK, different consultancy firms & $\begin{array}{l}\text { DGW, RWS, Deltares, coalition of nature } \\
\text { organizations }\end{array}$ \\
\hline \multirow[t]{2}{*}{ Rules and regulations } & Flood protection norms & Policy document: National Water Plan \\
\hline & HWBP criteria for subsidy & Plan: Ecological Robust Lake (ERL) \\
\hline \multirow[t]{2}{*}{ Discourse } & A basic flood protection shore dike & \multirow{2}{*}{$\begin{array}{l}\text { Ecological shore dike, with opportunities } \\
\text { for synergy between flood protection and } \\
\text { ecology }\end{array}$} \\
\hline & $\begin{array}{l}\text { Criteria of time, budget and cost-effectiveness, robustness and } \\
\text { feasibility }\end{array}$ & \\
\hline \multirow[t]{3}{*}{ Resources } & HWBP subsidy for dike reinforcement & Research budget \\
\hline & Responsibility for dike reinforcement & $\begin{array}{l}\text { Potential cost reduction by combining with } \\
\text { ERL }\end{array}$ \\
\hline & & $\begin{array}{l}\text { No formal say in HHNK dike } \\
\text { reinforcement }\end{array}$ \\
\hline $\begin{array}{l}\text { Knowledge base (complete } \\
\text { overview in Online } \\
\text { Resource 1) }\end{array}$ & $\begin{array}{l}\text { Exploration of knowledge base, studying and developing the shore } \\
\text { dike from a flood protection perspective. Directly linked to } \\
\text { decision-making }\end{array}$ & $\begin{array}{l}\text { Exploration of knowledge base based on } \\
\text { development of an ecological shore dike } \\
\text { design }\end{array}$ \\
\hline
\end{tabular}

\section{Interactions between knowledge arrangements}

In this section, we analyse and assess the interactions between the two knowledge arrangements using the modes of interaction.

\section{Interactions found between knowledge arrangements}

Among the actors in the respective knowledge arrangements, there was full awareness of each other's positions and activities. HHNK, DGW and RWS agreed to cooperate. In practice, this meant that the parties informed each other of ongoing activities, such as meetings and knowledge development, and RWS attended the dike reinforcement project meetings. The nature coalition presented their work at HHNK. However, formal lines of responsibility remained separate. HHNK depended on and reported to HWBP-2 and hired various consultants to build their knowledge base. RWS had an internal reporting structure and hired Deltares to build their knowledge base.

In each knowledge arrangement, specific rules and regulations applied. The flood protection knowledge arrangement was guided by flood protection norms as laid down in the Water Act, and the criteria for subsidies formulated by HWBP-2. In the ecological knowledge arrangement, these flood protection rules did not apply and were not actively considered in the development of knowledge. The policy ambition regarding synergy did not find its way into the dike reinforcement project.

Both knowledge arrangements had a typical discourse. However, elements of these discourses were borrowed from one another. Within the flood protection knowledge arrangement, implicit references were made to the integration of ecological factors, and the shore dike was referred to as a 'natural' solution to flood management (Van der Linde et al. 2012). In the ecological knowledge arrangement, the official objective of the synergy project related to the combination of ecology and flood protection. Despite these overlaps, differences remained prominent. Neither flood protection functionality nor the three crucial criteria for dike reinforcement (cost-effectiveness, robustness and appropriateness) were considered in the development of an ecological strategy. Furthermore, the shore dike was labelled a basic flood protection design in the flood protection knowledge arrangement.

Resources remained separate. Financial resources and responsibilities in the flood protection knowledge arrangement were exclusively used for flood protection. The cost-effectiveness criterion ensures that other functions (e.g. ecology) are not paid for through the HWBP-2 subsidy. The resources available in the ecology knowledge arrangement were devoted to knowledge development. Research for ecological project development and research for flood protection were strictly separated: 'everything done by Deltares is for ecology, and HHNK will not pay for that' (interview with Deltares representative, 2 July 2013).

Knowledge bases were developed in both knowledge arrangements by different parties (see Online Resource 1). The flood protection knowledge base was developed by consultancy firms hired by HHNK. The ecological knowledge base was developed by Deltares hired by the RWS and by a landscape designer hired by the coalition of nature organizations. When the shore dike concept was first introduced, the two knowledge bases were separated. The flood protection exploration study states: 'this exploration is independent of the exploration for possibilities for synergy between ecology and flood protection [...] 
commissioned by the Ministry' (Nieuwaal et al. 2010). DGW and RWS were not involved in the workshop that led to the shore dike, nor were they informed about the subsequent exploratory study. Successive flood protection reports applied a broader focus. The feasibility study by Haarman et al. (2010) and the definition study by Steetzel (2012) included an ecological alternative which was explicitly considered next to the BFP shore dike. In addition, Deltares researchers contributed to these studies with respect to the ecological aspects of the shore dike. Ecological reports (Smale et al. 2012; Noordhuis and Wichman 2012) were provided as appendices in the Steetzel (2012) study.

While the two knowledge bases were combined at certain points, these were not integrated. Ecological and flood protection knowledge were treated as two different knowledge bases and developed by different actors. Deltares was explicitly introduced 'for ecological possibilities and nature legislation' (Haarman et al. 2010, p.1), and in the definition study, the 'ecological design' consisted of the BFP profile with an added ecological element. At one point in the process, we found a form of integration: The workshop co-organized by HHNK and RWS (December 2011). This event was broadly attended by representatives of both knowledge arrangements and led to the shared conclusion that 'among experts broad support exists for an Ecological [...] [shore dike] design' (Deltares 2012, p. 4).

Cooperation among knowledge bases was not taken up in the crucial phase of decision-making, which is the selection of the preferred designs. The assessment report by Van der Linde et al. (2012) is an exclusive flood protection product. It was developed by two consultancy firms without input from ecology knowledge experts.

\section{Assessing interactions}

A hybrid mode of interaction emerged between the flood protection and the ecological knowledge arrangement combining elements of cooperation (on the actor, discourse and part of the knowledge base dimensions) and separation (on the rules and regulations, resources and part of the knowledge base dimensions).

The boundaries between these two knowledge arrangements proved semi-permeable. For example, ecological knowledge was included in flood protection reports, and discourses were partially shared. Moreover, actors from the ecological knowledge arrangement were invited and informed about activities related to the flood protection knowledge arrangement. However, at crucial moments (such as the selection of the preferred design) or when structural changes were envisaged (the double project objective), ecological influences were ignored. HHNK played the role of boundary keeper in rejecting the double objective, dividing research topics (ecology as something the Ministry pays for), and holding 'nature' outside the discourse by focusing on a BFP shore dike. This form of boundary management—which inhibited integration - can be understood from the independent position of HHNK in relation to the ecological domain and its highly dependent position related to the HWBP-2. HHNK saw no need to include ecology in the project (including ecology would not provide added value in terms of the design, financial resources, a coalition, etc.); conversely, including ecological components may have led to potential delays in the strict HWBP timeline. The boundary work in this flood protection knowledge arrangement was aimed at keeping the current boundary in place, but as long as no structural changes were foreseen, communication, sharing of information and other border crossings were allowed.

Unlike the flood protection knowledge arrangement, in the ecological knowledge arrangement, we distinguish initiatives aimed at changing the boundaries and the position of the arrangement. This was done by the proposal for a double objective and considered linkages with other projects (e.g. the shelter areas and an ERL). Such interventions would have improved the position of the ecological domain.

\section{Discussion on enabling greening flood protection}

Our case study was unsuccessful in terms of enabling GFP, and we found two different knowledge arrangements that were not integrated. In the discussion below, we deepen our understanding of the underlying mechanisms as well as potential strategies towards realizing GFP.

\section{Challenge: self-reinforcing knowledge arrangements}

The knowledge base and policy arrangement are interrelated and make up a knowledge arrangement. In the case study, we found that two relationships reinforced existing knowledge arrangements. The first relationship was the impact of the policy arrangement on the development of the knowledge base. Actors, resources, rules and discourses structure the process of knowledge production and the content of the developed knowledge. It affects who is involved in knowledge development, the design principles that are used and the knowledge concepts that are given priority and applied. This relationship is clearly illustrated in our case study. The policy arrangement enables a knowledge base that fits the design space provided in the policy arrangement. This design space includes the design criteria (such as cost-effectiveness, robustness and feasibility of the design), the central stakeholders (such as HWBP-2, HHNK and consultants) and also accepted 
methodologies for knowledge development. The design space offers limited room or few incentives for GFP knowledge development because: (1) GFP is multifunctional and does not meet the cost-effectiveness criterion, (2) it includes different and new design principles compared to those commonly used/applied (using other materials such as vegetation), requiring different research methodologies, and (3) the uncertainties inherent in GFP innovation negatively affect the robustness criterion. The second relationship is the impact of the knowledge base on the policy arrangement. The knowledge base determines the decision space. The knowledge base provides a particular set of options (e.g. design alternatives) to be decided upon. In the Markermeer dikes case study, the design alternatives did not include a GFP option. Consequently, the decision space was limited to flood protection options.

These two relationships form a vicious cycle (Fig. 4). The self-reinforcing feedbacks (Abel et al. 2011) sustain and even reinforce the predominant knowledge arrangement. This inhibits integration between knowledge arrangements, while supporting fragmentation. Self-reinforcing feedbacks lead to increased interconnectedness and less flexibility (Walker et al. 2006). In addition, path dependency preserves the chosen strategy. Knowledgepolicy interactions in the flood protection domain were formed over the last centuries (Van Koningsveld and Mulder 2004) and have led to the recognition of certain actors in knowledge development and research methodologies that are captured in handbooks and manuals or even further institutionalized. These aspects provide trust and allow for decision-making related to particular knowledge bases. However, it also implies a form of entrapment of a particular technology, which reduces the adaptability of infrastructural developments (Walker 2000). A paradigm shift, such as GFP, involves not just a change in design but a change in the policy arrangement. Adoption of new technological approaches is not feasible without the commitment of involved actors, legislation and resources (Berkhout 2002; Walker 2000).

\section{Enabling greening flood protection}

Below, we explore ways of dealing with fragmentation between knowledge arrangements by addressing the power imbalance and knowledge development. Both efforts may force a breakthrough in the vicious cycle (Fig. 4) and enable GFP.

\section{Handling fragmentation and power imbalance}

Fragmentation and power imbalances are central challenges to comprehensive decision-making (Huitema et al. 2009) and to GFP in particular, as the present case study demonstrated. The power imbalance is reflected in the independent position of the flood protection domain vis-àvis the dependent position of the ecological domain. While fragmentation allows for diversity and accommodation of different interests, it also leads to conflicting or inconsistent policies (Doremus 2009; Imperial 2005; Porzecanski et al. 2012). In addition, unequal distribution of power among different domains hampers integration (Imperial 2005; Wondolleck and Yaffee 2000). The literature on fragmentation points to strategies for improving coordination and cooperation or institutional restructuring to overcome this issue (Porzecanski et al. 2012; Huitema et al. 2009). While the former is about increasing the number of
Fig. 4 Reinforcement of knowledge arrangements

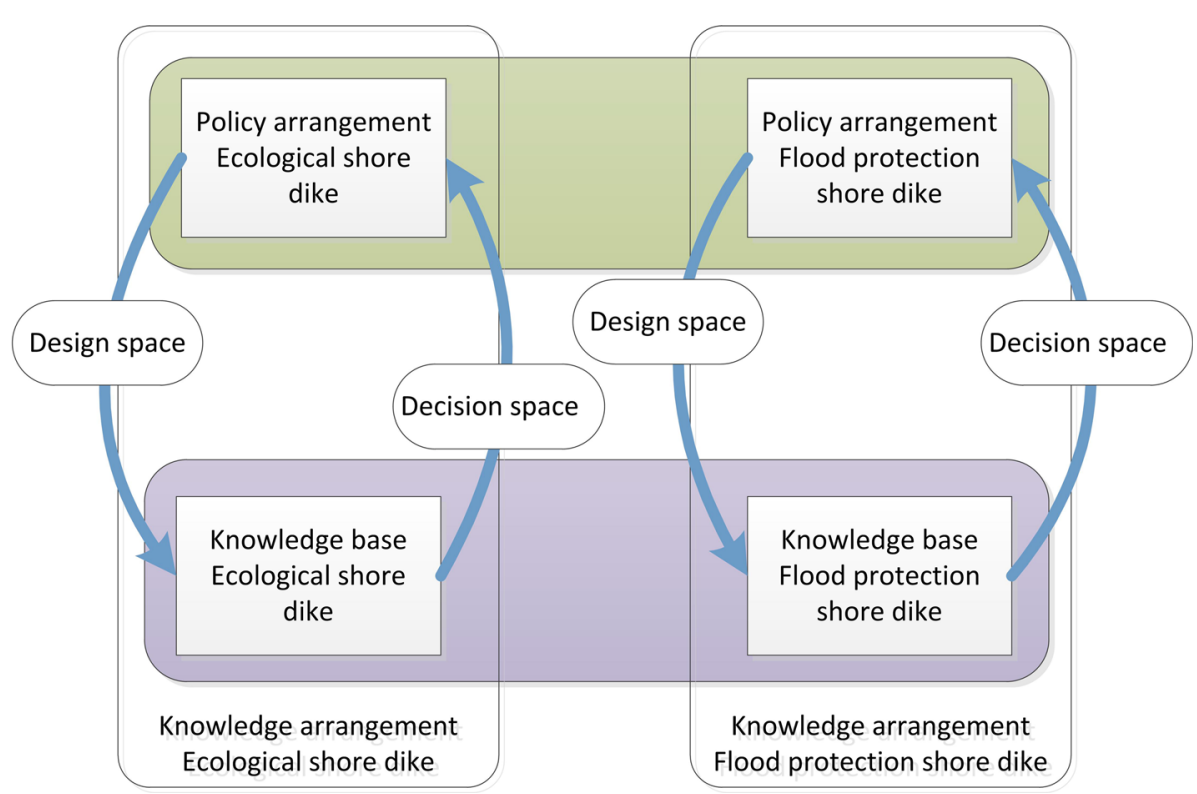


interactions between groups, the latter aims to fundamentally alter those interactions.

In an earlier paper on interacting knowledge arrangements, we assumed that cooperation is insufficient to enable GFP (Janssen et al. 2014b). The present case study confirms this idea. At the actor and discourse levels, we identified cooperation between knowledge arrangements; yet this cooperation did not enable GFP. It did not create a collective, combined policy arrangement that allowed for the development of a multifunctional GFP design. Rather, it maintained existing accountability structures and prevailing knowledge development methods. Our conclusion is that a form of structural change is needed to integrate existing knowledge arrangements to allow for GFP. Enabling GFP is a matter of institutional re-structuring rather than improving cooperation. This conclusion aligns with the findings of Lejano and Ingram (2009), who explain the effectiveness of policy instruments by their ability to create linkages and forge relationships that allow for new ways of knowing. Cash et al. (2003) highlight the crucial role of dual accountability-e.g. from both knowledge arrangements-in order to create linkages for effective knowledge development.

One strategy that supports institutional restructuring is coalition building. Meijerink and Huitema (2010) discerned three grounds for building or achieving coalitions. First, coalitions can be based on the shared beliefs and ideas of actors. In this case, actors share a similar disciplinary background or hold similar ideological viewpoints. In our case, we must conclude that this type of coalition is not very feasible. A second form of coalition is based on similarity in interests. While beliefs are different, an interest in realizing GFP may be held by all actors. These types of coalitions are based on so-called synergistic or win-win solutions. For GFP, finding such synergy seems plausible as scholars have emphasized the multifunctional nature of this type of solution (cf. Borsje et al. 2011; Van Slobbe et al. 2013). A third form of coalition is based on mutual dependency. Sharing financial resources is likely to ensure cooperation among actors. In the Markermeer dikes case study, however, the independent position of the flood protection domain prevented such a coalition. Hence, the most feasible GFP coalition is one based on shared interests or, when power is more equally distributed, mutual dependencies.

\section{Handling knowledge processes}

The presence of an ecological knowledge base in proximity to a flood protection knowledge base did not affect the design of the shore dike. In addition, an integrated knowledge base that included ecological and flood protection knowledge was not developed. As discussed above, this follows from internal knowledge arrangement dynamics: The ecological knowledge base does not fit the flood protection design space and is thus not included in the decision space. The presence of multiple knowledge bases in a project is suboptimal or undesirable when knowledge remains unused or forms the basis for a struggle between different knowledge sources (Deelstra et al. 2003). Moreover, it confirms the fact that decision-making often does not, or only to a limited extent, reflect the diversity of ideas (Brugnach and Ingram 2012; Feldman and Ingram 2009).

Integrating multiple knowledge sources requires a different approach to knowledge development, an approach that affects (1) the type of knowledge used, (2) the way knowledge is created and (3) how different parties are involved in knowledge production (Brugnach and Ingram 2012). Knowledge production processes should be collaborative activities in which stakeholders equally contribute to allow for the integration of different types of knowledge (Brugnach and Ingram 2012). Such participatory processes of knowledge development allow for the combination of multiple knowledge bases and for cognitive and strategic learning among the involved parties (Hommes et al. 2009). Multiple knowledge sources can be beneficial in that they stimulate learning processes (Eshuis and Stuiver 2005). Mutual learning processes allow for sharing of expertise, acquiring new information and building creative solutions by sharing perspectives (Wondolleck and Yaffee 2000). Additionally, learning allows for the development of a context-specific knowledge base. This is particularly relevant for GFP approaches as these designs are highly dependent upon the site-specific characteristics of ecosystems (Vikolainen et al. 2012; Bergen et al. 2001). Moreover, the acceptance of relevant knowledge is more likely when parties are jointly involved in its development (Eshuis and Stuiver 2005; Hommes et al. 2009; Cash et al. 2003).

\section{Conclusion}

Governments are increasingly challenged to consider uncertainties associated with climate change impacts on flood protection management. Greening flood protection (GFP) is an upcoming approach that specifically meets the requirement of no-regret, adaptive and flexible designs (Cheong et al. 2013), and it is advocated as a promising approach for dealing with climate change (Hale et al. 2009; Spalding et al. 2013). While knowledge and policies associated with GFP have developed rapidly over the last decade, the implementation of GFP has advanced less swiftly. This paper contributes to an understanding of the challenges of realising GFP in practice by studying the Dutch Markermeer dike reinforcement project. This case 
study illustrates that the implementation of GFP, at least in the Dutch context, is far from self-evident and requires structural changes in the organization of the flood protection domain.

By employing a knowledge arrangement perspective, we found a self-reinforcing cycle: a specific design space follows from the policy arrangement and a specific decision space follows from the knowledge base. In the flood protection knowledge arrangements, a flood protection knowledge base is created (matching the design space); consequently, decision-making is based on this flood protection knowledge base. Historically developed practices and path dependencies preserve chosen approaches. Such a cycle complicates the introduction of new and innovative approaches and thus inhibits multifunctionality. In addition to the fragmentation that follows from this self-reinforcing cycle, power is unequally distributed, which further inhibits a GFP approach: The flood protection field is very powerful and even independent in terms of resources, knowledge, legislation etc., while the ecological field is rather weak.

Enabling GFP requires that different knowledge arrangements merge into an integrated knowledge arrangement and thus a breakthrough in the self-reinforcing cycle. Increasing interactions or cooperation between actors of different knowledge arrangements is considered insufficient to achieve this breakthrough. Only structural changes in the nature of the interactions will allow development and acceptance of new GFP knowledge and designs. Such changes will alter the design space and facilitate commitments that allow for integrated GFP knowledge development. Potentially rewarding routes towards this integration are the exploration of shared interests in GFP (for different reasons) or the creation of mutual dependency between knowledge arrangements. Moreover, accountability to both knowledge arrangements and joint knowledge production are believed to be crucial factors affecting this process's success.

This case study illustrates that GFP is far from a mainstream practice, and its implementation requires serious effort and courage to facilitate a necessary break with historically constructed practices. However, as the limits of traditional flood protection are becoming more and more visible (as observed in this case study) and climate challenges become more urgent, the demand for GFP approaches will increase.

Acknowledgments We thank the employees of HHNK for their support in searching for data. We are grateful to the interview respondents for sharing information and time. This paper has benefited from discussions with Bas Borsje, Bertien Broekhans and Trudes Heems, as well as participants of the panel 'Making sense and managing sensitivities of designing and developing multipurpose technological artefacts' at IPA 2013 in Vienna. Arjen Francke performed interviews for the case study, of which we have taken full advantage. We thank the anonymous reviewers for their helpful comments. This research was financially supported by the Building with Nature program (www.ecoshape.nl).

\section{References}

Abel N, Gorddard R, Harman B, Leitch A, Langridge J, Ryan A, Heyenga S (2011) Sea level rise, coastal development and planned retreat: analytical framework, governance principles and an Australian case study. Environ Sci Policy 14(3):279-288. doi:10.1016/j.envsci.2010.12.002

Aerts JCJH, Botzen WJW (2013) Climate adaptation cost for flood risk management in the Netherlands. In: Hill D, Bowman MJ, Khinda JS (eds) Storm surge barriers to protect New York city. American Society of Civil Engineers, Reston, Virginia, pp 99-113. doi:10.1061/9780784412527.007

Aerts JCJH, Sprong TA, Bannink B (2008) Aandacht voor Veiligheid. http://www.deltacommissie.com/doc/Aandacht\%20voor\%20vei ligheid\%20.pdf

Ayanu Y, Jentsch A, Müller-Mahn D, Rettberg S, Romankiewicz C, Koellner T (2015) Ecosystem engineer unleashed: Prosopis juliflora threatening ecosystem services? Reg Environ Change 15(1):155-167. doi:10.1007/s10113-014-0616-x

Barbier EB, Koch EW, Silliman BR, Hacker SD, Wolanski E, Primavera J, Granek EF, Polasky S, Aswani S, Cramer LA, Stoms DM, Kennedy CJ, Bael D, Kappel CV, Perillo GME, Reed DJ (2008) Coastal ecosystem-based management with nonlinear ecological functions and values. Science 319(5861): 321-323. doi:10.1126/science.1150349

Bergen SD, Bolton SM, Fridley JL (2001) Design principles for ecological engineering. Ecol Eng 18(2):201-210. doi:10.1016/ S0925-8574(01)00078-7

Berkhout F (2002) Technological regimes, path dependency and the environment. Glob Environ Change 12(1):1-4. doi:10.1016/ S0959-3780(01)00025-5

Borsje BW, van Wesenbeeck BK, Dekker F, Paalvast P, Bouma TJ, van Katwijk MM, de Vries MB (2011) How ecological engineering can serve in coastal protection. Ecol Eng 37(2):113-122. doi:10.1016/j.ecoleng.2010.11.027

Brugnach M, Ingram H (2012) Ambiguity: the challenge of knowing and deciding together. Environ Sci Policy 15(1):60-71. doi:10. 1016/j.envsci.2011.10.005

Cash DW, Clark WC, Alcock F, Dickson NM, Eckley N, Guston DH, Jäger J, Mitchell RB (2003) Knowledge systems for sustainable development. Proc Natl Acad Sci USA 100(14):8086-8091. doi:10.1073/pnas.1231332100

Cheong SM, Silliman B, Wong PP, Van Wesenbeeck B, Kim CK, Guannel G (2013) Coastal adaptation with ecological engineering. Nat Clim Change 3(9):787-791. doi:10.1038/nclimate1854

Coen LD, Brumbaugh RD, Bushek D, Grizzle R, Luckenbach MW, Posey MH, Powers SP, Tolley SG (2007) Ecosystem services related to oyster restoration. Mar Ecol Prog Ser 341:303-307

Deelstra Y, Nooteboom SG, Kohlmann HR, Van Den Berg J, Innanen S (2003) Using knowledge for decision-making purposes in the context of large projects in The Netherlands. Environ Impact Assess Rev 23(5):517-541. doi:10.1016/S0195-9255(03) 00070-2

Deltares (2012) Verslag van de building with nature workshop: Oeverdijk als ecologisch alternatief voor dijkversterking? 6 Dec 2011, op Marken

Doremus H (2009) CALFED and the quest for optimal institutional fragmentation. Environ Sci Policy 12(6):729-732. doi:10.1016/j. envsci.2009.06.004 
Edelenbos J, Van Buuren MW, Van Schie N (2011) Co-producing knowledge: joint knowledge production between experts, bureaucrats and stakeholders in Dutch water management projects. Environ Sci Policy 14(6):675-684. doi:10.1016/j. envsci.2011.04.004

Eshuis J, Stuiver M (2005) Learning in context through conflict and alignment: farmers and scientists in search of sustainable agriculture. Agric Hum Values 22(2):137-148. doi:10.1007/ s10460-004-8274-0

Feldman DL, Ingram HM (2009) Making science useful to decision makers: climate forecasts, water management, and knowledge networks. Weather Clim Soc 1(1):9-21. doi:10.1175/2009 WCAS1007.1

Feldman MS, Khademian AM, Ingram H, Schneider AL (2006) Ways of knowing and inclusive management practices. Public Adm Rev 66(SUPPL. 1):89-99. doi:10.1111/j.1540-6210.2006. 00669.x

Gedan KB, Kirwan ML, Wolanski E, Barbier EB, Silliman BR (2011) The present and future role of coastal wetland vegetation in protecting shorelines: answering recent challenges to the paradigm. Clim Change 106(1):7-29. doi:10.1007/s10584-0100003-7

Gersonius B, Ashley R, Pathirana A, Zevenbergen C (2013) Climate change uncertainty: building flexibility into water and flood risk infrastructure. Clim Change 116(2):411-423. doi:10.1007/ s10584-012-0494-5

Giebels D, Van Buuren MW, Edelenbos J (2013) Ecosystem-based management in the Wadden Sea: principles for the governance of knowledge. J Sea Res 82:176-187. doi:10.1016/j.seares.2012. 11.002

Haarman FG, Capel A, De Kant M, Akkerman GJ, Noordhuis R, Wichman BGHM (2010) Dijkversterking Markermeerkust Hoorn-Amsterdam. De oeverdijk als extra alternatief? Royal Haskoning

Hale LZ, Meliane I, Davidson S, Sandwith T, Beck M, Hoekstra J, Spalding M, Murawski S, Cyr N, Osgood K, Hatziolos M, Van Eijk P, Davidson N, Eichbaum W, Dreus C, Obura D, Tamelander J, Herr D, McClennen C, Marshall P (2009) Ecosystem-based adaptation in marine and coastal ecosystems. Renew Resour J 25(4):21-28

Hegger D, Van Zeijl-Rozema A, Dieperink C (2012) Toward design principles for joint knowledge production projects: lessons from the deepest polder of The Netherlands. Reg Environ Change. doi:10.1007/s10113-012-0382-6

Hommes S (2008) Conquering Complexity, Dealing with uncertainty and ambiguity inwatermanagement, University of Twente, The Netherlands, Ph.D. thesis.

Hommes S, Vinke-de Kruijf J, Otter HS, Bouma G (2009) Knowledge and perceptions in participatory policy processes: lessons from the delta-region in the Netherlands. Water Resour Manag 23(8):1641-1663. doi:10.1007/s11269-008-9345-6

Huitema D, Mostert E, Egas W, Moellenkamp S, Pahl-Wostl C, Yalcin R (2009) Adaptive water governance: assessing the institutional prescriptions of adaptive (co-)management from a governance perspective and defining a research agenda. Ecol Soc 14(1):26

Hunt J, Shackley S (1999) Reconceiving science and policy: academic, fiducial and bureaucratic knowledge. Minerva 37(2):141-164. doi:10.1023/A:1004696104081

Imperial MT (2005) Using collaboration as a governance strategy: lessons from six watershed management programs. Adm Soc 37(3):281-320. doi:10.1177/0095399705276111

Janssen SKH, Mol APJ, Van Tatenhove JPM, Otter HS (2014a) The role of knowledge in greening flood protection. Lessons from the Dutch case study future Afsluitdijk. Ocean Coast Manag 95:219-232. doi:10.1016/j.ocecoaman.2014.04.015
Janssen SKH, van Tatenhove JPM, Otter HS, Mol APJ (2014b) Greening flood protection-an interactive knowledge arrangement perspective. J Environ Policy Plan. doi:10.1080/1523908X. 2014.947921

Kabat P, Van Vierssen W, Veraart J, Vellinga P, Aerts J (2005) Climate proofing the Netherlands. Nature 438(7066):283-284. doi: $10.1038 / 438283 a$

Katsanevakis S, Stelzenmüller V, South A, Sørensen TK, Jones PJS, Kerr S, Badalamenti F, Anagnostou C, Breen P, Chust G, D'Anna G, Duijn M, Filatova T, Fiorentino F, Hulsman H, Johnson K, Karageorgis AP, Kröncke I, Mirto S, Pipitone C, Portelli S, Qiu W, Reiss H, Sakellariou D, Salomidi M, van Hoof L, Vassilopoulou V, Vega Fernández T, Vöge S, Weber A, Zenetos A, Hofstede RT (2011) Ecosystem-based marine spatial management: review of concepts, policies, tools, and critical issues. Ocean Coast Manag 54(11):807-820. doi:10.1016/j. ocecoaman.2011.09.002

Korbee D, Van Tatenhove JPM (2013) Environmental governance for marine infrastructure: enabling and constraining conditions for ecodynamic development and design in marine infrastructural projects. J Environ Plan Policy Manag 15(4):533-550. doi:10. 1080/1523908X.2013.807211

Lammens E, Van Luijn F, Wessels Y, Bouwhuis H, Noordhuis R, Portielje R, Van Der Molen D (2008) Towards ecological goals for the heavily modified lakes in the IJsselmeer area, the Netherlands. Hydrobiologia 599(1):239-247. doi:10.1007/ s10750-007-9202-2

Lejano RP, Ingram H (2009) Collaborative networks and new ways of knowing. Environ Sci Policy 12(6):653-662. doi:10.1016/j. envsci.2008.09.005

Martin TG, Watson JEM (2016) Intact ecosystems provide best defence against climate change. Nat Clim Change 6(2):122-124. doi: $10.1038 /$ nclimate2918

McNie EC (2007) Reconciling the supply of scientific information with user demands: an analysis of the problem and review of the literature. Environ Sci Policy 10(1):17-38. doi:10.1016/j.envsci. 2006.10.004

Meijerink S, Huitema D (2010) Policy entrepreneurs and change strategies: Lessons from sixteen case studies of water transitions around the globe. Ecol Soc 15(2)

Ministerie van V\&W (2009) Nationaal Waterplan. https://www. rijksoverheid.nl/documenten/rapporten/2009/12/01/nationaalwaterplan-2009-2015

Mitsch WJ, Jørgensen SE (2003) Ecological engineering: a field whose time has come. Ecol Eng 20(5):363-377. doi:10.1016/j. ecoleng.2003.05.001

Mulder JPM, Hommes S, Horstman EM (2011) Implementation of coastal erosion management in the Netherlands. Ocean Coast Manag 54(12):888-897. doi:10.1016/j.ocecoaman.2011.06.009

Muñoz-Erickson TA (2013) Co-production of knowledge-action systems in urban sustainable governance: the KASA approach. Environ Sci Policy 37:182-191. doi:10.1016/j.envsci.2013.09. 014

Nieuwaal M, Sarink H, Van Hemert H, Eikelenboom JH (2010) Memo Haalbaarheidsstudie Voorlandkeringen Markermeerdijken

Noordhuis R, Wichman BGHM (2012) Ecologische uitwerking van het oeverdijkconcept. Op basis van ecologische uitgangspunten en grove inschatting waterkeringsveiligheid

Petts J, Brooks C (2006) Expert conceptualisations of the role of lay knowledge in environmental decisionmaking: challenges for deliberative democracy. Environ Plan A 38(6):1045-1059. doi:10.1068/a37373

PIANC (2011) PIANC Position paper 'Working with Nature' Oct 2008; revised January 2011. http://www.pianc.org/downloads/ envicom/WwN\%20Final\%20position\%20paper\%20January\% 202011.pdf 
Porzecanski I, Saunders LV, Brown MT (2012) Adaptive management fitness of watersheds. Ecol Soc 17(3):29

Rinaudo JD, Garin P (2005) The benefits of combining lay and expert input for water-management planning at the watershed level. Water Policy 7(3):279-293

Runhaar H, Mees H, Wardekker A, van der Sluijs J, Driessen PPJ (2012) Adaptation to climate change-related risks in Dutch urban areas: stimuli and barriers. Reg Environ Change 12(4):777-790. doi:10.1007/s10113-012-0292-7

Seijger C, Van Tatenhove JPM, Dewulf G, Otter HS (2014) Responding to coastal problems: interactive knowledge development in a US nature restoration project. Ocean Coast Manag 89:29-38. doi:10.1016/j.ocecoaman.2013.12.011

Smale AJ, De Vroeg H, Capel A (2012) Meerwaarde luwtestructuur voor de oeverdijk. Deltares

Spalding MD, Ruffo S, Lacambra C, Meliane I, Hale LZ, Shepard CC, Beck MW (2013) The role of ecosystems in coastal protection: adapting to climate change and coastal hazards. Ocean Coast Manag 90:50-57. doi:10.1016/j.ocecoaman.2013.09.007

Spencer KL, Harvey GL (2012) Understanding system disturbance and ecosystem services in restored saltmarshes: integrating physical and biogeochemical processes. Estuar Coast Shelf Sci 106:23-32

Steetzel HJ (2012) Definitiestudie oeverdijk ontwikkeling M.E.R.-rijp alternatief hoofdrapport. Arcadis

Stuurgroep_TMIJ (2008) Investeren in Markermeer en IJmeer. Ontwikkelingsperspectief en actieplan

Sullivan W, Rees J (2008) Clean language. Revealing metaphors and opening minds. Crown House Publishing Limited, Carmarthen

Temmerman S, Meire P, Bouma TJ, Herman PMJ, Ysebaert T, De Vriend HJ (2013) Ecosystem-based coastal defence in the face of global change. Nature 504(7478):79-83. doi:10.1038/nature12859

Turnhout E, Hisschemöller M, Eijsackers H (2007) Ecological indicators: between the two fires of science and policy. Ecol Ind 7(2):215-228. doi:10.1016/j.ecolind.2005.12.003

Van Broekhoven S, Vernay AL (2011) Integrating functions for a sustainable urban system. Crossing boundaries between domains. Paper presented at the IGS-SENSE conference, Enschede, The Netherlands, 19-21 Oct

Van Buuren MW (2009) Knowledge for governance, governance of knowledge: inclusive knowledge management in collaborative governance processes. Int Public Manag J 12(2):208-235. doi:10.1080/10967490902868523

Van Buuren MW, Edelenbos J (2004) Why is joint knowledge production such a problem? Sci Public Policy 31(4):289-299. doi:10.3152/147154304781779967

Van Buuren MW, De Bruin E, Zweegman G-J, Becker L, Raadgever $\mathrm{T}$ (2010) Strategieën voor integrale kustontwikkeling in een versnipperd institutioneel systeem. APPM, Zoetermeer

Van de Riet AWT (2003) Policy analysis in multi-actor policy settings: navigating between negotiated nonsense and superfluous knowledge. Eburon Publishers, Delft

Van den Hoek RE, Brugnach M, Hoekstra AY (2012) Shifting to ecological engineering in flood management: introducing new uncertainties in the development of a Building with Nature pilot project. Environ Sci Policy 22:85-99. doi:10.1016/j.envsci.2012. 05.003

Van den Hoek RE, Brugnach M, Mulder JPM, Hoekstra AY (2013) Analysing the cascades of uncertainty in flood defence projects: how "not knowing enough" is related to "knowing differently". Glob Environ Change. doi:10.1016/j.gloenvcha.2013.11.008

Van der Brugge R, Rotmans J, Loorbach D (2005) The transition in Dutch water management. Reg Environ Change 5(4):164-176. doi:10.1007/s10113-004-0086-7
Van der Linde A, Melissen C, M. T, M. M, Schultz S (2012) Dijkversterking Hoorn-Amsterdam Adviesnota voorkeursalternatief. Royal HaskoningDHV/Arcadis

Van der Molen F, van der Windt HJ, Swart JAA (2016) The interplay between knowledge and governance: insights from the governance of recreational boating in the Dutch Wadden Sea area, 1981-2014. Environ Sci Policy. doi:10.1016/j.envsci.2015.02. 012

Van Helsdingen A, Lawley J (2012) Zuiver belevingsonderzoek: het vermijden van onbedoelde beïnvloeding in kwalitatief onderzoek. KWALON 17(3):43-50

Van Koningsveld M, Mulder JPM (2004) Sustainable coastal policy developments in the Netherlands. A systematic approach revealed. J Coast Res 20(2):375-385. doi:10.2112/15515036(2004)020[0375:SCPDIT]2.0.CO;2

Van Koningsveld M, Stive MJF, Mulder JPM, De Vriend HJ, Ruessink BG, Dunsbergen DW (2003) Usefulness and effectiveness of coastal research: a matter of perception? J Coast Res 19(2):441-461

Van Meurs GAM (2008) Dijkversterking Edam-Amsterdam. QuickScan dubbeldoelstelling Veiligheid en verbeteren Ecologie. Deltares

Van Meurs GAM, Mens AMJ, Altamirano MA (2010) Quick scan ecologische meerwaarde alternatief oeverdijk. Dijkversterking op het traject Hoorn-Amsterdam. Deltares

Van Slobbe E, De Vriend HJ, Aarninkhof S, Lulofs K, De Vries M, Dircke P (2013) Building with nature: in search of resilient storm surge protection strategies. Nat Hazards 65(1):947-966. doi:10. 1007/s11069-012-0342-y

Van Tatenhove JPM, Arts B, Leroy P (eds) (2000) Political modernisation and the environment. The renewal of environmental policy arrangements. Kluwer, Dordrecht

Van Wesenbeeck BK, Mulder JPM, Marchand M, Reed DJ, de Vries MB, de Vriend HJ, Herman PMJ (2014) Damming deltas: a practice of the past? Towards nature-based flood defenses. Estuar Coast Shelf Sci 140:1-6. doi:10.1016/j.ecss.2013.12.031

Van Winden A, Maka C (2012) Oeverdijken: kans voor veiligheid en natuur

Vikolainen V, Bressers H, Lulofs K (2012) Implementing eu natura 2000 at the project level: lessons from the Veluwe border lakes in the Netherlands. Public Adm 90(4):1016-1031. doi:10.1111/j. 1467-9299.2011.01971.x

Walker W (2000) Entrapment in large technology systems: institutional commitment and power relations. Res Policy 29(7-8): 833-846. doi:10.1016/S0048-7333(00)00108-6

Walker B, Gunderson L, Kinzig A, Folke C, Carpenter S, Schultz L (2006) A handful of heuristics and some propositions for understanding resilience in social-ecological systems. Ecol Soc 11(1): 13

Wichman BGHM, Noordhuis R, De Vries MB, Van de Wal M, De Rijk S (2011) Synergie veiligheid en ecologie. Verkenning oeverdijk met TBES maatregelen. Deltares

Wiering M, Arts BJM (2006) Discursive shifts in Dutch river management: 'Deep' institutional change or adaptation strategy? Hydrobiologia 565(1 SPEC. ISS.):327-338. doi:10.1007/1-40205367-3_22

Woltjer J, Al N (2007) Integrating water management and spatial planning: strategies based on the Dutch experience. J Am Plan Assoc 73(2):211-222. doi:10.1080/01944360708976154

Wondolleck JM, Yaffee SL (2000) Making collaboration work: lessons from innovation in natural resource management. Island Press, Washington 